\title{
Methodology for compiling the ethnographic miniature parks' exhibits nomenclature of the Armenian nation
}

\author{
Ashot Safaryan*, Yuri Safaryan, and Ruben Sargsya \\ National University of Architecture and Construction of Armenia, 0009, Yerevan, Republic of \\ Armenia
}

\begin{abstract}
The method of compiling the ethnographic miniature parks' exhibits nomenclature of the Armenian people is proposed. Brief information about the historical Armenian capitals, which are included in the main exhibition basis, is presented. For each of the historical capitals, on the basis of the conducted research, the layout $3 \mathrm{D}$ visualizations, which will be presented in the form of architectural model-exhibits in the parks, have been developed by the authors. The virtual reconstruction of certain significant objects of historical and architectural heritage located both on the territory of Armenia and abroad, which are proposed to be included in the exposition, has also been carried out.
\end{abstract}

\section{Introduction}

Ethnographic parks-museums of the Armenian people combine the models of museums of time, space and creative and scientific activities of the Armenian people, they are designed to perform the following functions - historical succession, educational, recreational and entertaining, research, communicative [1-6]. The basis of the exposition of the ethnic theme parks of the Armenian people will be monuments of architectural, historical and cultural heritage, as well as the expositions dedicated to the lifestyle and tradition of the Armenian people [5-7].

Monuments of architecture and urban planning are not only particular buildings and structures, objects of civil, industrial, fortification, religious architecture, engineering art, but also architectural ensembles and complexes, historical centers, district, streets, squares $[5,6,8-12]$, the ruins of the ancient planning and development of cities, which are either completely preserved or completely or partially destroyed. The process of architectural monument presentation in a museum exhibition involves either its direct presentation or its interpretation in the form of a layout, in particular, by means of using multimedia technologies (computer-based, interactive applications having the following main elements - text, graphics, animations, video, and sound). Completely destroyed and existing only in the form of archaeological excavations, or lost part of the volume and/or some details of architectural monuments can be reconstructed using the contemporary methods [13], as well the 3D modeling methods, based on modern information technologies. The necessary

*Corresponding author: ayusafaryan@gmail.com 
condition for the existence and development of the future museum, as well as the virtual museum is information technologies. Due to information technologies in the conditions of limited physical space and time frames, it became possible to expand the museumre source (exhibits) potential.

\section{Methodology for compiling the nomenclature of ethnographic parks' exhibits of the Armenian nation}

It is proposed to make a list of exhibits and to classify them, according to the following criteria:

- chronological -the monuments are grouped by the date of their construction,

- territorial -the monuments are grouped in Armenia - by regions and beyond-by countries of the world,

- stylistic affiliation - the clarification of the monument's place in the general course of art development makes it possible to determine the relationship of architecture of different styles and nations,

- original functional purpose - the following monuments will be presented: Armenian historical capitals [10], fortifications, ancient settlements, monuments of civil architecture (residential, public buildings), other structures (small architectural forms, khachkars, etc.).

\section{Brief historical overview}

During the concept implementing of creating a network of Armenian ethnic theme parks, the following historical objects, as the exhibition basis, will be presented - historical Armenian capitals, fortresses, ancient settlements of ancient settlements, samples of civil architecture (residential, public buildings), religious architecture, and others (small architectural forms, khachkars, and others) [5, 6, 9, 10, 11, 14].

\subsection{Capitals}

In the issue of organizing and preparing the models of capitals, certain difficulties arise regarding those cities which exact location is unknown, or there is not enough information to obtain a holistic shape of the layout. These cities are Tigranakert, Vagharshapat, Yervandashat and Bagaran. In order to get a complete picture of the capitalswith no available information, the authors decided to present them in the form of several structures located within the historical borders of the capitals.

Over the centuries, Armenia has had 12 capitals on the territory of historical Armenia. The models included all 12 capitals of Armenian history-Tushpa-Van, Armavir, Yervandashat, Artashat, Tigranakert, Vagharshapat, Dvin, Bagaran, Kars, Ani, Sis, Yerevan.Below the information about the capitals, including a 3D reconstruction of these complexes, as well as photos of the buildings that are still preserved, is presented,which will be necessary for the construction of models.

Tushpa-Wan. The city was built in the 9th century BC during the kingshipof the Van kingdom king Rus A. Crude brick fortresses on stone foundations were built across the entire surface of the spine of the rock. The urban part was located on the adjacent plain. The rebuilding of the city over the centuries has fundamentally changed the fortifications of the Van kingdom, replacing them with new ones. The preservation of partially preserved structures of the Urartian period is due to their rock climbing. Modern fortresses made of raw brick belong to the Middle Ages and later stages, as a result, it was decided to present 
the fortresses of the capital Tushpa-Wan from the 19th to the first half of the 20th century with the existing fortifications. It should be noted, that the urban part of the city was completely destroyed in the first half of the 20th century and only photographs allow us to reconstruct their appearance and structures (Fig.1,2).

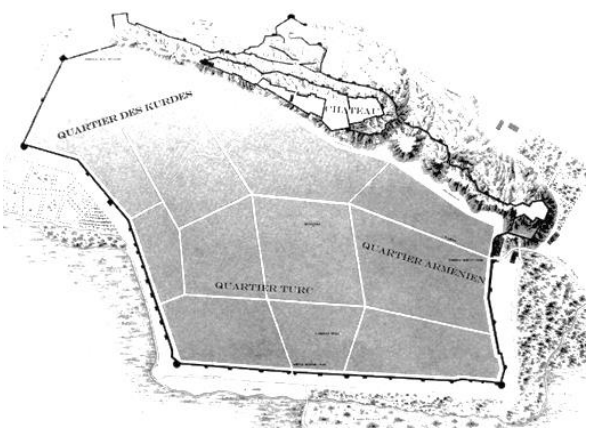

Fig. 1.The layout structure of the Van city in the first half of the 20th centuryby to Charles Texier

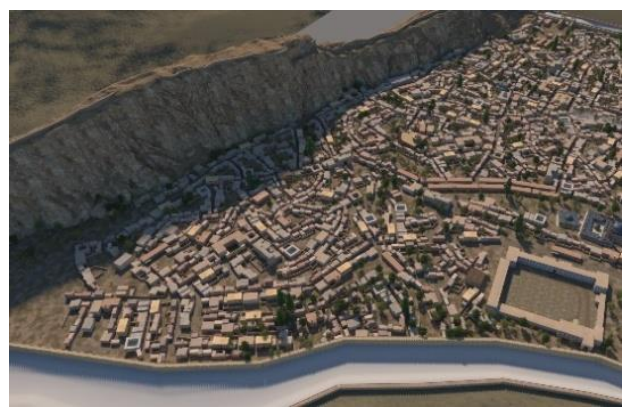

Fig. 2.Reconstruction of the Van city, by Erkan Konyar

Armavir. The capital Armavir was formed on the site of the Argishtikhinili fortress built by King Argishti I in the Kingdom of Van. Argishtikhinili was located on two hills, one of which was of an administrative and economic kind, and the other of a religious and religious kind. In the 7 th century $\mathrm{BC}$, two fortresses were burned and destroyed by the enemy, but before the first, the administrative hill of Argishtikhinili was not restored, another hill, already under Yervanduni, turned and became the capital of Armavir.It was decided to show both the hill of the capital of Armavir with its citadel, and its paired hill, which in the period of the Van kingdom formed its immediate part (Fig. 3, 4, 5).

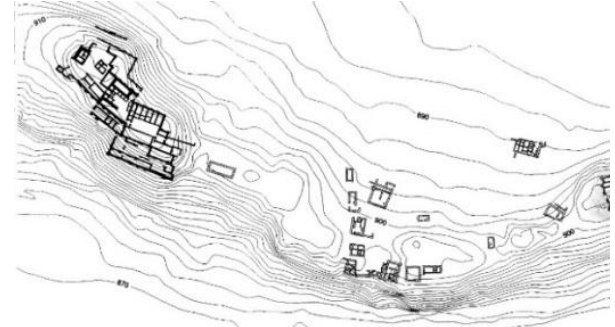

Fig. 3. Master plan of the fortresses of Argishtikhinili-Armavir, by K. Kafadaryan

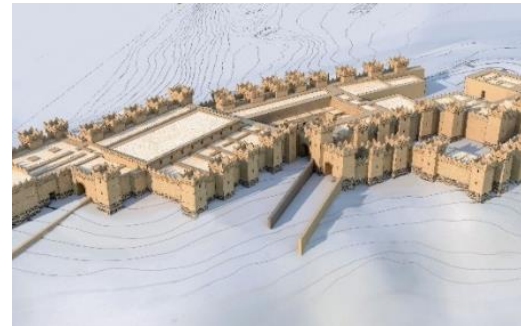

Fig. 4. 3D reconstruction of the Argishtikhinili fortress, by R. Sargsyan

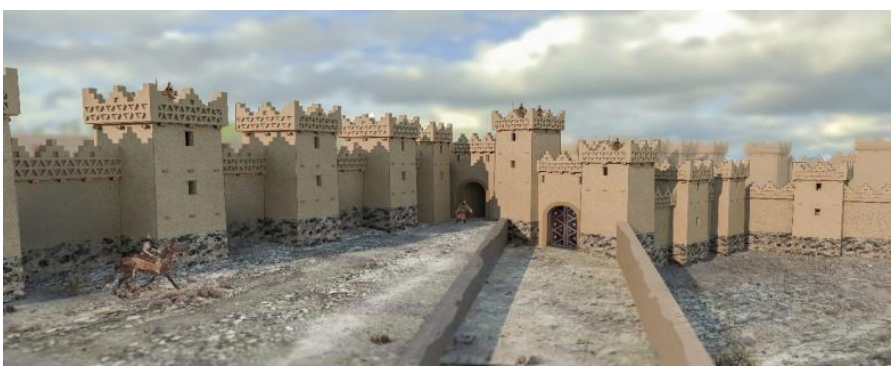

Fig. 5. Reconstruction of the main entrance to the Argishtikhinili fortress, by R. Sargsyan

Yervandashat.The capital of Yervandashat was built by Yervanduni, on a rock adjacent to the Arax River, and on the adjoining plain. The topography of the latter ones is known, as 
well the references to the fortress and the city of the historian Khorenatsi were left. However, nothing remains of the ancient city of Ernvadashat, which served as the capital, and the lack of necessary excavations does not allow to give it a complete picture. The monumental Palace structure excavated and studied on the territory is the only example that can be shown in the form of a model (Fig.6).

Archaeological excavations conducted under the supervision of Felix Ter-Maritirosov in 2006 revealed a monumental structure built on the Araks Riverbanks, which, according to the archaeologist, was the palace of Yervand Arshakuni, the king who founded the capital Yervandashat. It is known from historical references that the king planted a forest where he released the animals and turned it into a place of royal hunting, calling it "the genesis of forest". The excavated structure, according to Felix Ter-Martirosov, is a palace built at this place, where could the king rest after the hunt. This unique structure built from Yervandashat, the only one of its kind and as a representative of the capital of Yervandashat, was included in the list of models that will be presented in the park.

Artashat. The capital of Artashat was founded by Artashes A in the 2 century BC in the crater of the Arax and Metsamor rivers. Fortresses were found on 14 hills, each of which had its own unique significance, such as the garrison residence, the cult part, the artisans' hill, and so on. On the plain, where the rivers Arax and Metsamor were dammed, a residential part of the city was found. From the excavations, the preserved foundations of the fortress structures were discovered, through which one can get a vision of the Citadel, as well as the city.

As part of the organization of the park, it is planned to present the capital hills, on which fortresses and walls will have already been placed. The layout will also show the rivers Arax and Metsamor, at the point of mixing of which the capital was located (Fig.7, 8).

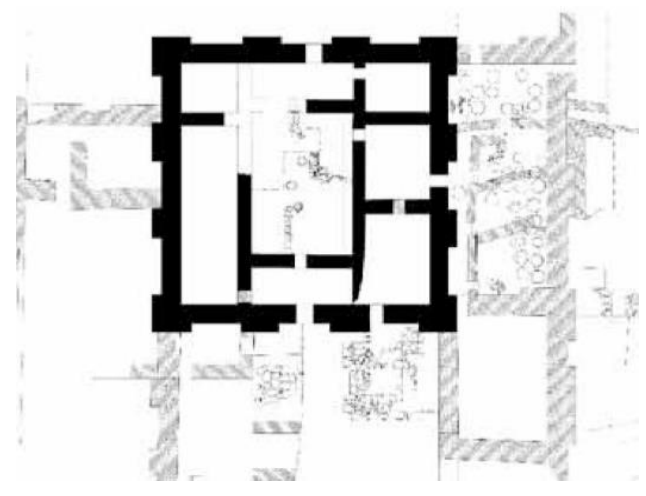

Fig. 6. Drawing of the palace structure built by king Yervand, by F. Ter-Martirosov

Vagharshapat.The structures typical of the fortress approaches of that time have not been preserved from the Vagharshapat, which served as the period of the Arsacids. The layout of the capital has undergone drastically changes, leaving no previous structures.

Based on the above-mentioned problems, it was decided to show the Cathedral of Etchmiadzin from Vagharshapat in the form of a model, which, although in itself has undergone drastically changes over the centuries, is one of those unique structures that is located in its original place and is a monument to the proclamation of Christianity in Armenia in 301 as the state religion (Fig. 9). 


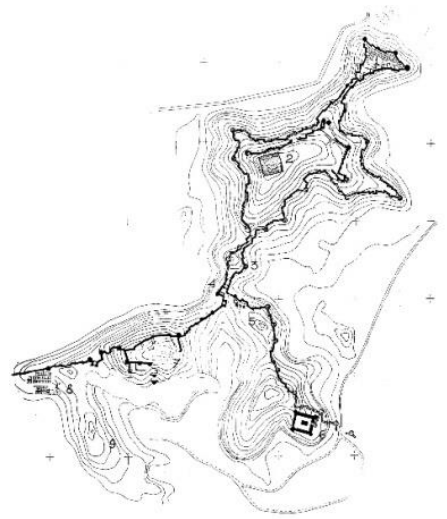

Fig. 7.Master plan of the capital Artashat, by A. Tonikyan

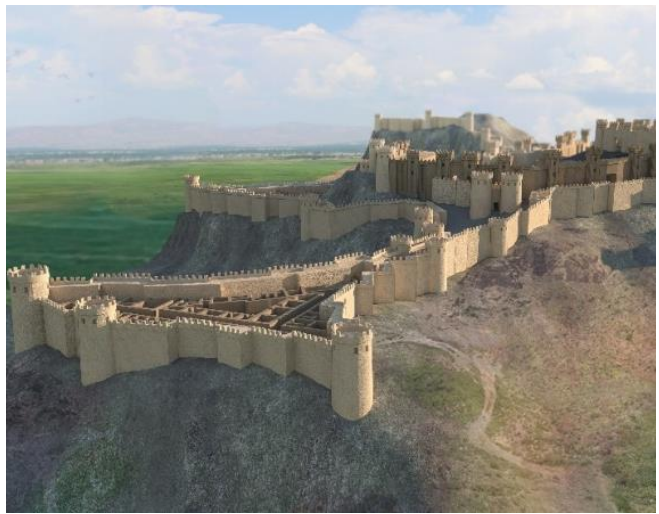

Fig. 8. 3D reconstruction of the capital Artashat, by R. Sargsyan

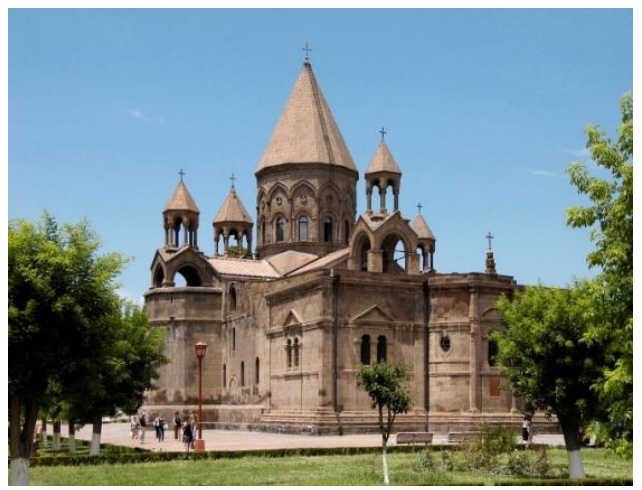

Fig. 9. Etchmiadzin Cathedral, representing the capital of Vagharshapat

Dvin. The capital of Dvin was founded by Khosrov B. Arshakuni. It was located on two hills, on one of which was the citadel, and on the other-the spiritual center as the Church of St. Nicholas. St. Gregory the Illuminator Basilica and the Catholicos' Palace. Two hills were surrounded by water, and the city was located on the plain. The information is sufficientfor building a layout and to show its outstanding buildings (Fig.10, 11).

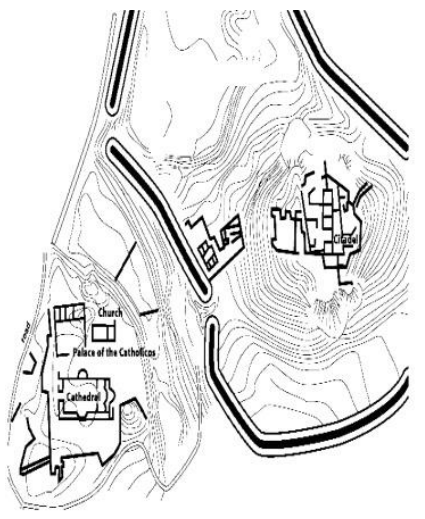

Fig. 10.Layout of the capital of Dvin, by K. Kafadaryan

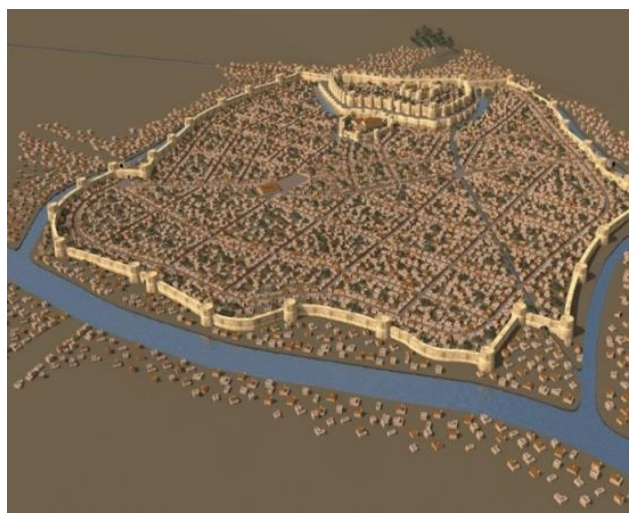

Fig. 11.Reconstructionof the Dvincapital by A. Ghazaryan 
Kars. Kars was proclaimed the capital by Abas Bagratuni. At the time of King Ashot I (885-890), Smbat A (890-914) and Ashot B Yerkat (914-928) the capitals of Armenia were Dvin, Bagaran, and Yervandashat. However, in the context of ongoing wars, they did not justify the capitalrole, since they were located in the vicinity of the Arab Emirates. True, Ashot B Yerkat finally overthrew the Arab oppression, but his brother and the next king Abas Bagratuni (928-953), having ascended the throne, moved the capital of his state to Kars, it was far from the borders of the Arab Emirates and was a more secure city. Next to Abas Bagratuni-King Ashot G. Vogormats (953-977) - founded a new capital-cosmic Ani (Fig.12).

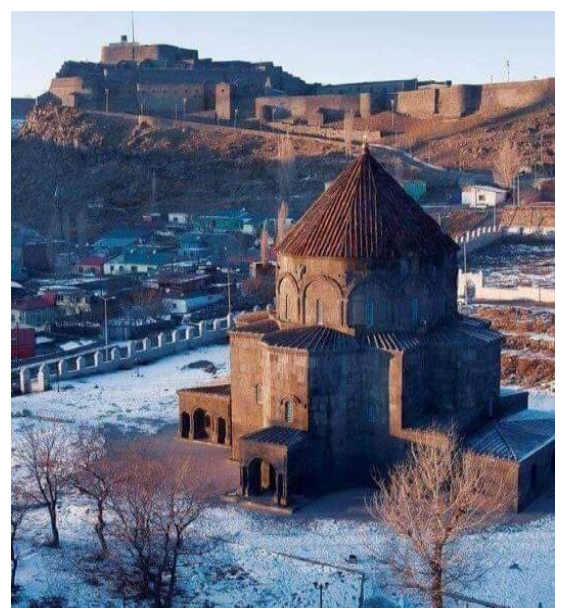

Fig. 12. Kars Fortress and Arakelots Monastery panorama

Ani.The first mention of Ani dates back to the early Middle Ages-the 5 century, as one of the Kamsar ducesprincely house fortresses. From the Armenian chroniclers, this is evidenced by Yeghishe and Kazar Parpetsi. At the beginning of feudal relations, Great Armenia was under the Arshakid kingdom. During the Arab domination, in the early 9th century, the Armenian prince Ashot Bagratuni Msaker (790-826) bought the provinces of Arsharunik and Shirak from the Kamsarakans through the Anifortress. Ani is known as "the city of thousands and one churches", of these, the most famous is the cathedral. In the Middle Ages, numerous trade roads passed through here. The city had many palaces and public structures. Ani was surrounded by two walls: Ashotashen and Smbatashen, and in the center of the city was a citadel. According to the Armenian sources, Ani had 100-200 thousand inhabitants (Fig.13, 14).

Yerevan. The capital Yerevan was founded in the 8th century BC by the king of the Van kingdom Argishti I. As the Erebuni fortress, which was restored in the following centuries, Yerevan had one of its first residential areas. Arin-Berd Hill, located on the south-eastern suburb of Yerevan, preserves the remains of one of the most significant monuments of the archaeological heritage in the Republic of Armenia-the ruins of the Erebunicity. It was built in $782 \mathrm{BC}$ by one of the greatest kings of the Urartian empire, Argishti I (approx. 786-765/764 BC), who according to the Khorkhor Protocol, resettled6600 soldiers here from the Khate and Tsupan countries located in the western part of the Armenian Highlands.

The leaders of the Armenian SSR tried to decorate Yerevan and highlight their name among other capitals of the world. Under Sargis Kasyan, in 1920-1921, a lot of work was done to bring production enterprises into operation, stop hunger and epidemics, open schools, put the water utility in order, clean up streets and squares. At the invitation of Alexander Myasnikyan, artist Martiros Saryan, architect Alexander Tamanyan composer 
Alexander Spendiaryan, and poet Shushanik Kurginyan and many others, moved to Armenia and settled in Yerevan. Tamanyan was destined to design a new master plan for Yerevan (Fig. 15, 16, 17).
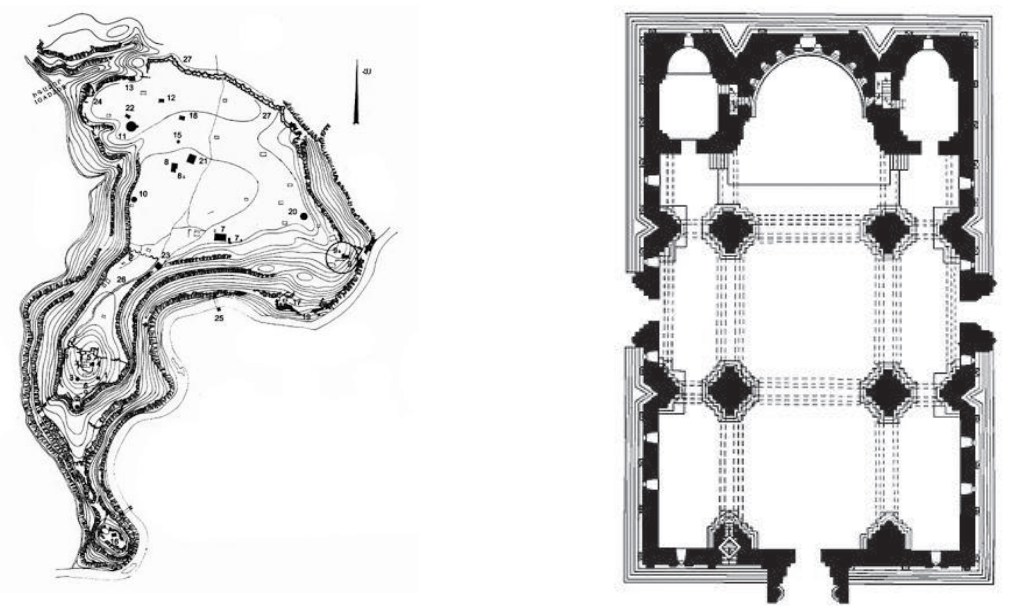

Fig. 13. Master plan of the capital of Ani and the Cathedral, by T.Toramanyan

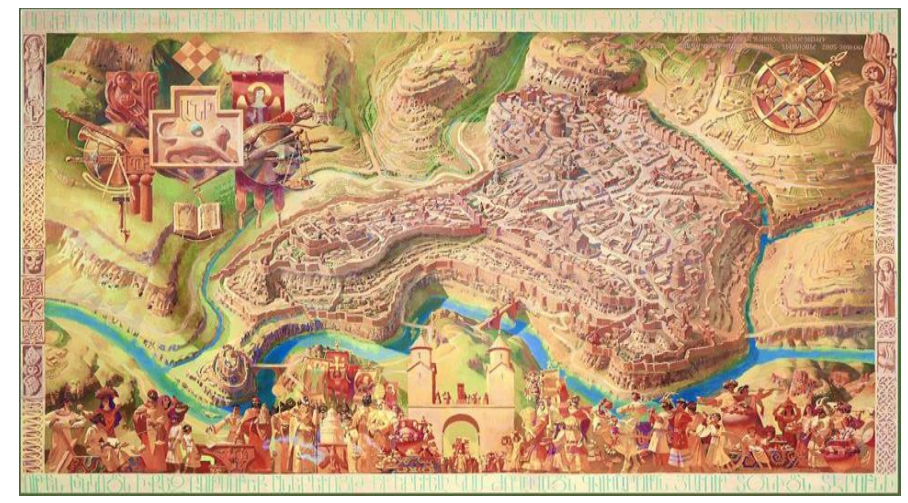

Fig. 14. The reconstructionof the capital Ani applicable to fulfillthe layout, by A. Abroyan

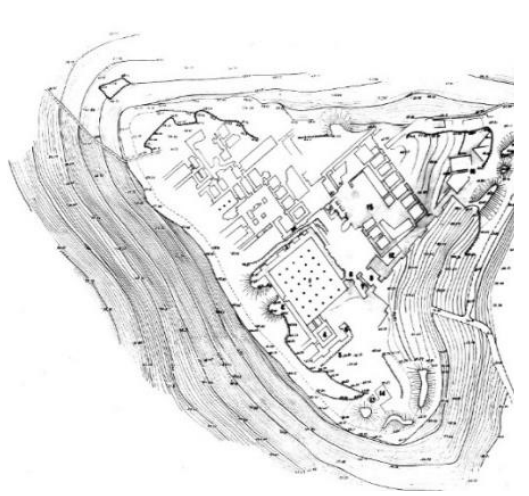

Fig. 15. Master plan of the Erebuni fortress, by K. To Hovhannisyan

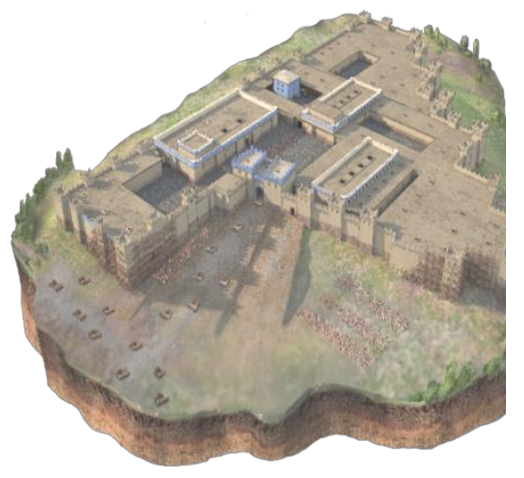

Fig. 16. 3D reconstruction of the Erebuni Fortress, by R. Sargsyan 


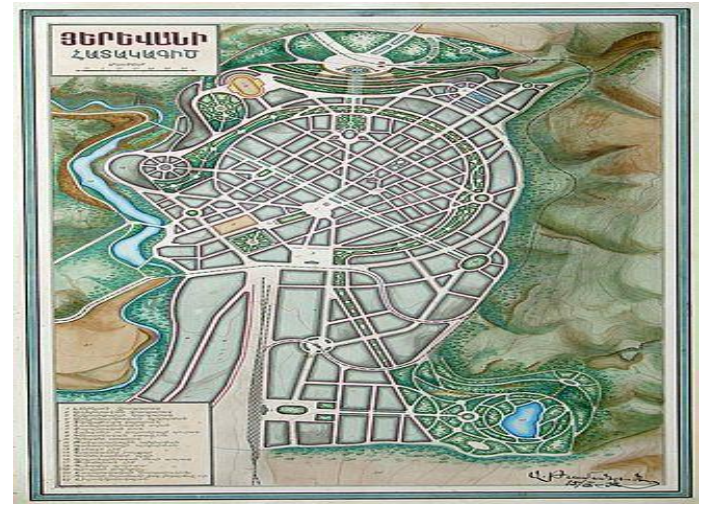

Fig. 17. Master plan of Yerevan,by A. Tamanyan

In the 1 century BC, Tigran II the Great, in the conditions of his powerscale, founded several capitals that bore his name-Tigranakert. The central place in it, located on the territory of the present-day cities of Diarbekir-Silvan, in Western Armenia, has not yet been considered and studied. Therefore, there is no information about the general appearance of the latter. In the Artsakh region of historical Armenia there is one of the Tigranakerts founded by him, which was first investigated in 2006. Although it has not been fully excavated, however, on the basis of the already opened walls, it is possible to conclude its general structural features (Fig. 18).

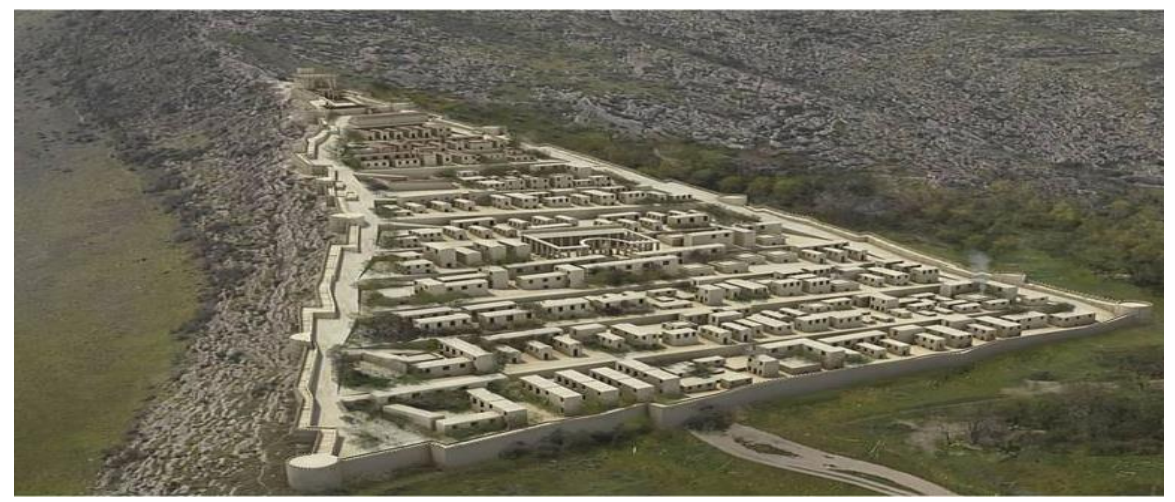

Fig. 18. The 3D reconstruction of the Artsakh Tigranakert,layout by L. Kirakosyan

\subsection{Fortresses}

Teishebaini (Karmir Bloor).Teishebaina Fortress, also known as Karmir Bloor, was founded by Rusa B in the 7 century BC. It is located on the territory of present-day Yerevan and is the second Urartian fortress of its type in the city. The castle was two-storeyed and a multicellular house was excavated in the city part, it is important in its type because this approach is known for the multicellular houses built after the last one in Rome.

The castle and the multi-section house in the urban part of Teishebaini will be presented as separate layouts in a section to show its features (Fig.19, 20, 21). 


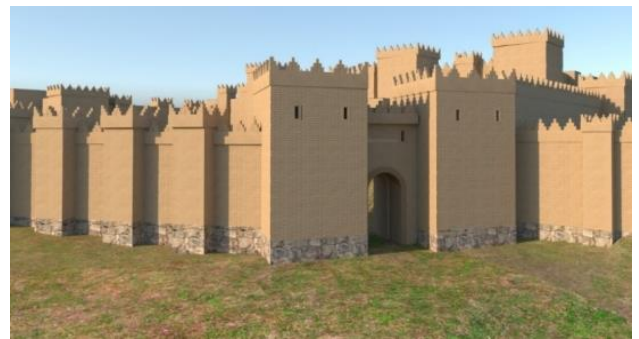

Fig. 19. Layout of the Teishebain fortress, by B. Piotrovsky

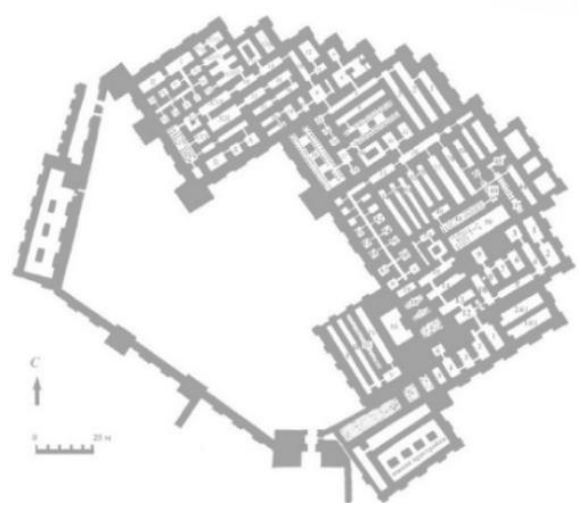

Fig. 20. Reconstruction of the Teishebain fortress, by R. Sargsyan

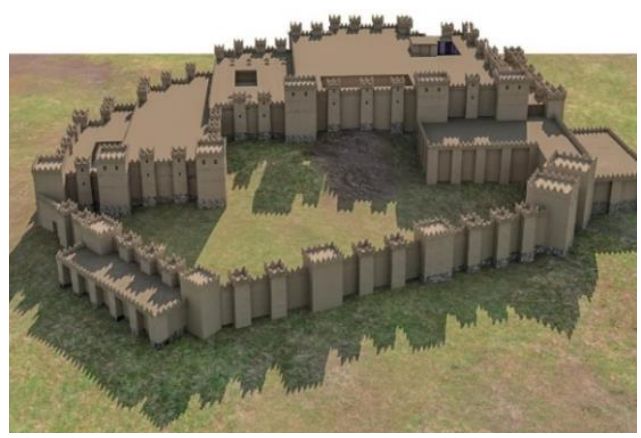

Fig. 21.Reconstruction of the fortressmain entrance, by R. Sargsyan

\subsection{Public buildings}

The models of multi-section house located in the urban part of Teishebaini, palace of the Catholicos of Dvin, residential buildings with a round and circular plan of the ancient settlement of Shengavit, residential buildings of the head house type, residential buildings of Gorisis are proposed to be presented in the park exposition.
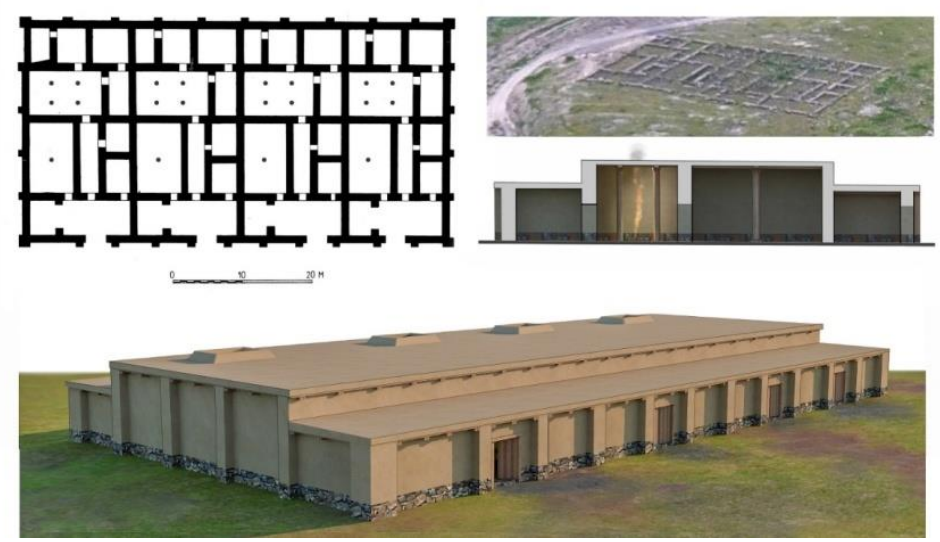

Fig. 22. Reconstruction of a multi-section house in the city district, by R. Sargsyan 
The multi-section house, located in the urban part of Teishebaini, was built in the 7 th century BC during the time of King Rusa B of the Van kingdom (Fig.22).

Shengavit. The ancient settlement "Shengavit", belonging to the Kur-Araks culture, inhabited by 4 millennium, is a set of dwellings with a round and circular layout. In the center of the circular shelters there are clayhearth. This settlement was located in the southwestern part of present-day Yerevan and is the oldest settlement (Fig. 23, 24).

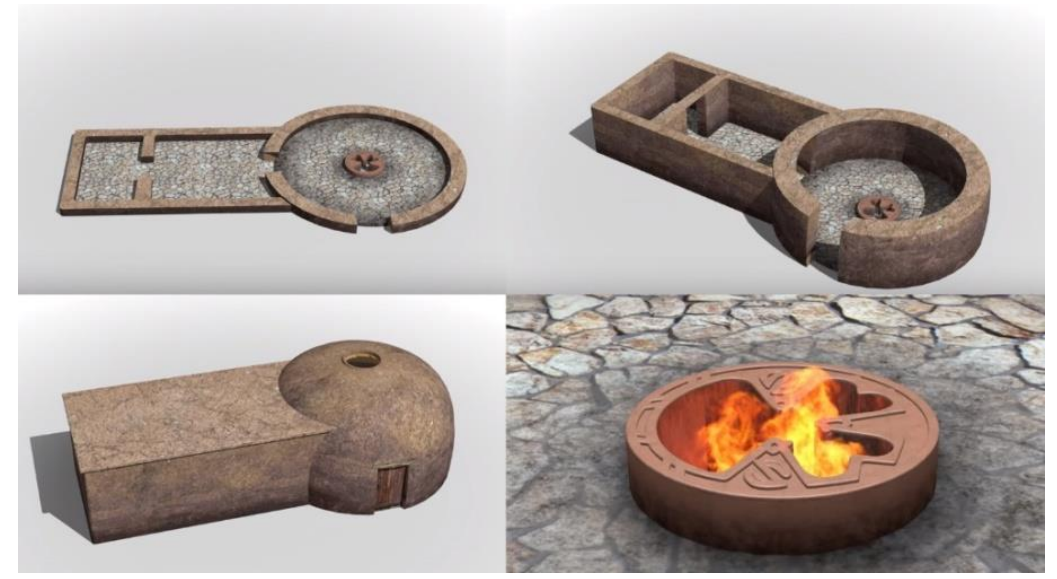

Fig. 23. Reconstruction of the Shengavit settlement, by P. Frankyan

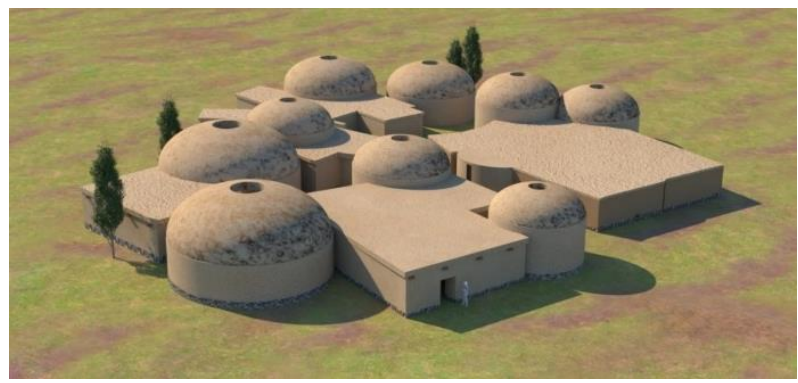

Fig. 24. Reconstruction of housingin the form of a complex,by R. Sargsyan

The exhibition will also include the models of following Armenian architectural monuments: Gandzasar, Kazanchetsots, Amaras, Noravank, Tsitsernavank, Dadivank, Haghpatavank Monastery, Akhtamar, Sanahin, Zvartnots, Garni, Hripsime, Gayane, Khor Virap.

\section{Conclusion}

Architectural monuments, as well as expositions dedicated to the life and customs of the Armenian people will be displayed in the ethnographic parks. The method of compiling the ethnographic parks' exhibits nomenclature of the Armenian people and their classification according to the following characteristics: chronological, territorial, stylistic affiliation, the original functional purpose of the monuments. When implementing the concept of creating a network of Armenian ethnographic parks both on the territory of Armenia and abroad - in the countries with a large Armenian diaspora, in each case, depending on the location, conditions and opportunities, in addition to the main basis of the exhibition, real historical monuments can also be presented, combined with the models of existing monuments, as well as virtual reconstruction (based on 3D modeling) of completely or partially destroyed 
monuments, which will significantly enrich the exposition. Based on the research the authors developed and presented $3 \mathrm{D}$ reconstruction of historic Armenian capitals and architectural monuments (3D reconstruction of the main entrance of the Argishtikhinili fortress, the main entrance to the Argishtikhinili fortress, the capital of Artashat, the capital of Dvin, the fortress of Erebuni, Tigranakert, the fortress of Teishebain and the main entrance to the temple, an apartment building in the City district of Teishebain, the Catholicos' robe of Dvin, the dwellings of the ancient settlement of Shengavit, the dwellings of Shengavit) which will be presented in the exhibition parksin form of the exhibitsmodels.

This work has been carried out in the frame of "Architectural issues of the creation of ethnographic park-museums of the Armenian people" theme (code: 19YR-2A004) and "Preservation and development of the urban planning and architectureresearch laboratory" program, financed by the Science Committee of Republic of Armenia.

\section{References}

1. M.A. Gasparyan, Yu.A. Safaryan, Advanced Materials Research 1020, 702-706, (2014)

2. B.V. Gnedovsky, E.D. Dobrovolskaya, Open-air museums. Development of principles of formation and structure (Moscow, 1987)

3. L.A. Fotii et al, Creation of architectural and ethnographic complexes in open-air museums: Guidelines (Leningrad, 1985)

4. A.S. Marcus, H.T. Levine, The Social Studies - University of Connecticut 102,104-109 (2011).

5. A.Yu. Safaryan, IOP Conf. Ser.: Mater. Sci. Eng. 913, 032030 (2020). https://iopscience.iop.org/article/10.1088/1757-899X/913/3/032030/pdf

6. A.Yu. Safaryan, IOP Conf. Ser.: Mater. Sci. Eng. 698, 033053 (2019). https://doi:10.1088/1757-899X/698/3/033053

7. A.Yu. Safaryan, Scientific Papers of NUACA II (65), 96-101 (2017).

8. Yu.A. Safaryan, M.A. Gasparyan, A.A. Aloyan, IET Conference Publications 1-30, 357 (2011).

9. A.Yu. Safaryan, Yu.A. Safaryan, IOP Conf. Ser.: Mater. Sci. Eng. 913, 032015 (2020). https://iopscience.iop.org/article/10.1088/1757-899X/913/3/032015/pdf

10. A.Yu. Safaryan, O.S. Subbotin, A.Yu. Safaryan, R.G.Sargsyan, IOP Conf. Ser.: Mater. Sci. Eng. 1083, 012029 (2021). https://iopscience.iop.org/article/10.1088/1757899X/1083/1/012029

11. O.S. Subbotin, IOP Conf. Ser.: Mater. Sci. Eng. 913, 032021 (2020). https://iopscience.iop.org/article/10.1088/1757-899X/913/3/032021/meta

12. A.A. Aloyan, A.Yu. Safaryan, Advanced Materials Research 1020, 875-878 (2014). https://www.scientific.net/AMR.1020.875

13. A.Yu. Safaryan, IOP Conf. Ser.: Mater. Sci. Eng. 698, 033047 (2019). https://doi:10.1088/1757-899X/698/3/033047

14. A.Yu. Safaryan, Prerequisites and prospects of formation of ethnographic parks in the Republic of Armenia, Proceedings of 7 th International Conference Contemporary Problems of Architecture and Construction, Florence-Italy, 727-732 (2015). 